\title{
Qualidade microbiológica de alimentos
}

\author{
Microbiological quality of food \\ Calidad microbiológica de los alimentos
}

\section{Resumo}

Atualmente, a análise microbiológica é de extrema relevância no ramo alimentício, pois, com ela, é possível conhecer as condições em que o alimento foi processado, os riscos que ele pode oferecer ao consumidor final, se o produto terá a vida útil pretendida, além de verificar se os padrões de especificações microbiológicos para alimentos estão sendo seguidos adequadamente. O presente trabalho teve como objetivo verificar a qualidade sanitária de variados alimentos 
a partir da presença de microrganismos indicadores, como mesófilos, coliformes totais e coliformes termotolerantes. Dentre os alimentos analisados, muitos se mostraram altamente contaminados, apontando péssimas condições sanitárias, tornando-os impróprios para o consumo. As amostras de salsicha indicaram um padrão microbiológico aceitável, não atingindo altas populações de mesófilos e coliformes que poderiam desfavorecer o produto. Isso já não acontece com os queijos analisados, já que foram as amostras mais contaminadas do presente trabalho, alcançando números superiores a $107 \mathrm{NMP} / \mathrm{g}$. Com este trabalho, foi possível observar que consumidores estão sujeitos a adquirir produtos considerados impróprios para o consumo e, infelizmente, no Brasil, nem sempre há regulamentação que limite uma quantidade máxima microrganismos indicadores, não impedindo assim a comercialização de alimentos altamente contaminados, podendo gerar danos à saúde de quem venha a consumi-los. Para que tal ato seja no mínimo evitado, as autoridades sanitárias devem atuar fazendo uma melhor fiscalização dos produtos e orientando os manipuladores sobre boas práticas sanitárias.

Palavras-chave: Coliformes fecais; Doenças; Mesófilos; Microrganismos indicadores; Saúde pública.

\begin{abstract}
Currently, the microbiological analysis is of extreme relevance in the food industry, because with it, it is possible to know the conditions under which the food was processed, the risks that it can offer to the final consumer, if the product has the desired useful life, besides to verify that microbiological standards for food standards are being followed properly. The present work aims to verify the sanitary quality of various foods from the presence of indicator microorganisms, such as mesophiles, total coliforms and thermotolerant coliforms, which indicate the possibility of fecal contamination. Among the foods analyzed, many were highly contaminated, pointing to poor sanitary conditions, making them unfit for consumption. Samples of sausage indicated an acceptable microbiological standard, not reaching high populations of mesophiles and coliforms that could disadvantage the product. This is no longer the case with the cheeses analyzed, since they were the most contaminated samples of the present project, reaching numbers greater than $107 \mathrm{NMP} / \mathrm{g}$. With the work, it was possible to observe that costumers are subject to purchase a products considered to be unapproved for consumption and, unfortunately, in Brazil, there is not always a regulation that limits a maximum quantity of microorganisms indicators, thus not preventing the commercialization of foods contaminated, and can cause harm to the health of those who consume them. In order for such an act to be avoided at least, health authorities should act by better monitoring of products and guiding handlers on good sanitary practices.
\end{abstract}

Keywords: Diseases; Fecal coliforms; Indicator microorganisms; Mesophiles; Public health.

\title{
Resumen
}

Actualmente, el análisis microbiológico es sumamente relevante en la industria alimentaria, ya que es posible conocer las condiciones en las que se procesó el alimento, los riesgos que puede ofrecer al consumidor final, si el producto tendrá la vida útil prevista, además de para verificar que las normas de especificación microbiológica para alimentos se estén siguiendo correctamente. Este estudio tuvo como objetivo verificar la calidad sanitaria de diversos alimentos a partir de la presencia de microorganismos indicadores, como mesófilos, coliformes totales y coliformes termotolerantes. Entre los alimentos analizados, muchos estaban altamente contaminados, lo que apunta a malas condiciones sanitarias, lo que los hace inadecuados para el consumo. Las muestras de embutidos indicaron un estándar microbiológico aceptable, no alcanzando altas poblaciones de mesófilos y coliformes que pudieran desfavorecer el producto. Esto no ocurre con los quesos analizados, ya que fueron las muestras más contaminadas en el presente trabajo, alcanzando cifras superiores a $107 \mathrm{NMP} / \mathrm{g}$. Con este trabajo se pudo observar que los consumidores están sujetos a la compra de productos considerados no aptos para el consumo y, lamentablemente, en Brasil no siempre existen normativas que limitan una cantidad máxima de microorganismos indicadores, no impidiendo así la venta de alimentos altamente contaminados. , lo que puede generar daños en la salud de quienes los consumen. Para que tal acto se evite al menos, las autoridades sanitarias deben actuar haciendo una mejor inspección de los productos y orientando a los manipuladores sobre las buenas prácticas sanitarias.

Palabras clave: Coliformes fecales; Enfermedades; Mesófilos; Microorganismos indicadores; Salud pública.

\section{Introdução}

A presença de microrganismos patogênicos, ou de suas toxinas, em alimentos representa um risco à saúde pública, pois podem causar sérios prejuízos à saúde de quem os consome, além de gerar perdas econômicas e também diminuindo a vida útil desses produtos. A contaminação microbiana, então, está diretamente associada com a saúde pública e econômica do mundo, devendo ser evitada por meio de boas práticas de manipulação (Souza et al., 2003). Para Franco e Almeida (1992), muitas contaminações microbianas são indesejáveis e nocivas. Para se conhecer a existência de possíveis deficiências higiênicas, são pesquisados grupos de microrganismos chamados indicadores, e também os patogênicos que podem se desenvolver no alimento. 
Além de existirem vários veículos de contaminação de alimentos, existem vários fatores que contribuem para aumentar a probabilidade dessa contaminação. A higiene do manipulador e de tudo o que entra em contato com o alimento deve ser adequada e é de extrema importância para a produção segura e inócua do produto final. A deficiência na higienização representa um risco à saúde dos consumidores (Hattori \& Klaus, 2013).

Segundo Hayes (1995), a prática de exames para detecção de microrganismos patogênicos em alimentos é inabitual pela falta de equipamentos adequados. Para reverter tal obstáculo, procura-se nos alimentos a presença de microrganismos capazes de causar infecções. A presença desses microrganismos pode ser detectada pela pesquisa de indicadores, que indicam o potencial de contaminação presente no alimento, e são de grande significância quando da avaliação da segurança e qualidade microbiológicas de alimentos.

Para Ribeiro (2008), os microrganismos indicadores revelam muito sobre a qualidade microbiológica dos alimentos, pois podem indicar a presença de contaminação fecal, o grau de deterioração do produto, como o alimento foi processado e armazenado, indicam erros das condições sanitárias, revelam a vida útil de prateleira, além de indicar a presença de bactérias potencialmente patogênicas. Em geral, microrganismos indicadores são utilizados para avaliar aspectos de qualidade a sanidade dos alimentos.

De acordo com Doyle, Beuchat e Montiville (1997), um microrganismo indicador deve ser de fácil detecção, deve ser distinguido de outros microrganismos da microbiota do alimento, não deve estar presente na contaminação natural do alimento, deve ter como habitat apenas o trato intestinal de mamíferos e apresentar alta resistência ao ambiente extra-intestinal.

Os microrganismos indicadores podem ser classificados em dois grupos, de acordo com a International Commission on Microbiological Specifications for Foods (ICMSF, 1994): I) microrganismos que não oferecem riscos à saúde como os mesófilos, psicrotróficos, termófilos, bolores e leveduras. II) microrganismos que causam risco baixo ou indireto à saúde: coliformes totais e termotolerantes.

Vários fatores contribuem para que ocorra a contaminação de um alimento, mas os principais são: as condições precárias de higiene do local onde se produz, falta de equipamentos e utensílios adequados e falta de higiene pessoal, principalmente dos manipuladores. É extremamente importante a conservação e a higiene das instalações e dos equipamentos, além de um alto grau de conhecimento e preparo dos manipuladores para que evitar contaminação nos alimentos. Erros de manipulação e o não cumprimento das normas higiênicas favorecem a contaminação por microrganismos patogênicos, que por sua vez, podem se multiplicar em números suficientes para causar enfermidades ao consumidor (Ferreira, 2006).

Pinheiro e Wada (2010) dizem que os equipamentos e utensílios com higienização deficiente têm sido responsáveis, isoladamente ou associados a outros fatores, por surtos de doenças de origem alimentar ou por alterações de alimentos processados. Para Freitas (1995), cortadores de frios, cortadores de legumes, bandejas, pratos, talheres, tabuleiros, placas de manipulação, amaciadores de carne, entre outros, devem passar constantemente por uma avaliação microbiológica para controle da eficiência do procedimento de higienização, evitando-se a contaminação dos alimentos produzidos.

Na produção de alimentos, a qualidade da matéria-prima e seu processamento adequado são fatores indispensáveis para garantir um produto final seguro que não apresente riscos à saúde do consumidor (Pinheiro e Wada, 2010).

A análise microbiológica em alimentos pode ser realizada, então, a fim de investigar a presença ou a ausência de microrganismos no produto analisado, para quantificação dos microrganismos presentes e para identificação e caracterização de diferentes espécies microbianas (Ribeiro, 2008).

De acordo com o seu comportamento em relação à temperatura ótima de multiplicação, as bactérias estão subdivididas em grupos. Dentre esses grupos, destacam-se as bactérias mesófilas, que são capazes de se multiplicar entre $10{ }^{\circ} \mathrm{C}$ e $45^{\circ} \mathrm{C}$, sendo $30^{\circ} \mathrm{C}$ a temperatura ideal. Elas incluem a maioria dos contaminantes dos alimentos de origem animal, podendo atingir altas contagens quando o alimento é mantido à temperatura ambiente. Este é o grupo de microrganismos mais usado para 
determinar contaminação alimentar, pois é o mais frequente e em maior número. São capazes de indicar se a limpeza, a desinfecção e o controle da temperatura durante os processos de tratamento industrial, transporte e armazenamento foram realizados de forma adequada. Esta determinação permite também obter informação sobre a alteração incipiente dos alimentos, sua provável vida útil, a falta de controle no descongelamento dos alimentos ou desvios na temperatura de refrigeração estabelecida (Silva, 2002).

Os microrganismos termófilos são aqueles que possuem capacidade de resistir a temperaturas extremamente altas, chegando a $90{ }^{\circ} \mathrm{C}$, embora sua temperatura ideal de multiplicação esteja ao redor de $55^{\circ} \mathrm{C}$. Apesar de não serem frequentes no leite, sua presença pode causar sérios danos quando mantidos em temperatura elevada (ICMSF, 1994). Assumem importância maior em alimentos que foram termicamente processados, já que podem resistir à temperatura de processamento.

Já os psicrotróficos apresentam temperatura ótima de multiplicação entre 20 e $30^{\circ} \mathrm{C}$, embora alguns sejam capazes de se reproduzir em temperaturas abaixo de $10^{\circ} \mathrm{C}$. A pasteurização é suficiente para eliminá-los, porém, produtos oriundos de seu metabolismo, como esporos e enzimas, podem resistir e causar alterações nas características anormais do alimento. As enzimas mais importantes produzidas por essas bactérias são a protease e a lipase. Essas bactérias são normalmente encontradas na água e em vasilhames que não foram lavados adequadamente (Oliveira et al., 2012).

Segundo Franco (2003), os coliformes totais são um grupo capaz de fermentar a lactose com produção de gás, quando incubados a $36^{\circ} \mathrm{C}$, por 48 horas. Fazem parte desse grupo predominantemente bactérias pertencentes aos gêneros Escherichia, Enterobacter, Citrobacter e Klebsiella. Apenas Escherichia coli tem como hábitat primário o trato intestinal, pois, os outros são encontrados também em outros ambientes como na vegetação e no solo. Consequentemente, a presença de coliformes totais no alimento não indica, necessariamente, contaminação fecal recente.

Os coliformes termotolerantes correspondem aos coliformes totais que apresentam a capacidade de continuar fermentando lactose com produção de gás, quando incubadas a temperaturas de $44-45{ }^{\circ} \mathrm{C}$. São os que mais se aproximam de uma indicação fecal, no entanto, a pesquisa da presença de Escherichia coli é útil quando é desejável determinar se houve contaminação fecal (Franco, 2003).

Os enterococos são bastante resistentes ao calor e podem sobreviver à pasteurização ou ao tratamento térmico do leite. Os enterococos não são usuais como indicadores de contaminação fecal, pois são encontrados em outros ambientes além do trato intestinal como solo, vegetais e alimentos, e também por serem mais resistentes, sobrevivendo a temperaturas desfavoráveis e ação de bactericidas. Sua presença em números elevados em alimentos indica práticas sanitárias inadequadas ou exposição do alimento a condições que permitam seu desenvolvimento (Franco, 2003).

Com este trabalho, objetivou-se avaliar a qualidade microbiológica de variados alimentos de origem animal pela pesquisa dos microrganismos indicadores mais comuns, que são: microrganismos mesófilos; coliformes totais; coliformes termotolerantes.

\section{Metodologia}

As amostras foram constituídas por cinco tipos de alimentos de origem animal, de marcas diferentes e encontradas em supermercados varejistas, da maneira como estavam expostas para a comercialização, totalizando 30 amostras. Os alimentos analisados foram: carne moída bovina; carne de frango; linguiça frescal; queijo minas frescal (sem identificação de serviço de inspeção); e salsicha a granel.

Imediatamente após a aquisição, as amostras foram transportadas nas próprias embalagens comerciais em caixas isotérmicas com gelo para o Laboratório de Microbiologia do Centro Universitário Moura Lacerda e imediatamente analisadas. As pesquisas realizadas foram a contagem de bactérias mesófilas (exceto para queijo minas frescal) e determinação do Número Mais Provável (NMP) de coliformes totais e termotolerantes. 
Para a quantificação de bactérias mesofílicas, foram realizadas diluições decimais das amostras e $1 \mathrm{ml}$ de cada diluição foi adicionado em placas de Petri estéreis em duplicatas. Na sequência foram vertidos de 15 a $20 \mathrm{ml}$ de ágar padrão para contagem (PCA) em temperatura próxima a $42{ }^{\circ} \mathrm{C}$ e, então, foi feita a homogeneização em forma de oito (“8”). Após a solidificação do ágar, as placas foram invertidas e incubadas em estufa bacteriológica a $35{ }^{\circ} \mathrm{C}$ por 48 horas. Após o período, foram contadas colônias das placas que apresentaram entre 25 e 250 unidades formadoras de colônia (UFC), cujo resultado foi multiplicado pelo valor de diluição para obter-se a contagem por grama (g) de amostra (Brasil, 2003).

Para determinação de coliformes totais, foi usada a técnica de tubos múltiplos. Desta forma, $1 \mathrm{ml}$ de cada diluição foi transferido para tubos de ensaio contendo caldo lauril sulfato de sódio com tubo de Durham invertido, em triplicatas. Após a inoculação, o material foi incubado em estufa bacteriológica a $35{ }^{\circ} \mathrm{C}$ por 24 a 48 horas. Na presença de resultados sugestivos (turvação do meio com bolha de gás no interior do tubo de Durham), foi retirada uma alíquota, com ajuda de alça de semeadura, que foi transferida para caldo lactosado bile verde brilhante com tubo de Durham invertido. Incubou-se então, a $35^{\circ} \mathrm{C}$ por 24 a 48 horas, e na sequência os resultados positivos foram considerados coliformes totais. Para determinação do número mais provável, foi utilizada uma tabela própria para esta finalidade (Brasil, 2003).

Para determinação de coliformes termotolerantes, repetiu-se o mesmo procedimento citado para os coliformes totais, com exceção de que o meio utilizado foi o caldo EC (ao invés do caldo lactosado bile verde brilhante), que foi incubado em banho-maria a $45^{\circ} \mathrm{C}$ por 24 a 48 horas (Brasil, 2003).

\section{Resultados e Discussão}

Foram analisadas 30 amostras de alimentos de origem animal. Os resultados obtidos se encontram na Tabela 1. 
Tabela 1 - Resultados das amostras colhidas nos supermercados em 2017.

\begin{tabular}{|c|c|c|c|}
\hline AMOSTRAS & $\begin{array}{l}\text { Mesófilos } \\
\text { (UFC/g) }\end{array}$ & $\begin{array}{l}\text { Coliformes Totais } \\
(\mathrm{NMP} / \mathrm{g})\end{array}$ & $\begin{array}{l}\text { Coliformes Termotolerantes } \\
\text { (NMP/g) }\end{array}$ \\
\hline Salsicha 1 & $9,8 \times 10^{2}$ & $<3,0$ & $<3,0$ \\
\hline Salsicha 2 & $1,2 \times 10^{3}$ & $<3,0$ & $<3,0$ \\
\hline Salsicha 3 & $2,6 \times 10^{3}$ & $<3,0$ & $<3,0$ \\
\hline Salsicha 4 & $3,8 \times 10^{3}$ & $<3,0$ & $<3,0$ \\
\hline Salsicha 5 & $5,5 \times 10^{3}$ & $<3,0$ & $<3,0$ \\
\hline Salsicha 6 & $6,2 \times 10^{3}$ & 3,6 & 3,6 \\
\hline Salsicha 7 & $9,3 \times 10^{3}$ & 3,6 & $<3,0$ \\
\hline Salsicha 8 & $1,0 \times 10^{4}$ & 21 & $<3,0$ \\
\hline Linguiça 1 & $1,0 \times 10^{3}$ & $<3,0$ & $<3,0$ \\
\hline Linguiça 2 & $1,81 \times 10^{3}$ & 3,6 & $<3,0$ \\
\hline Linguiça 3 & $1,1 \times 10^{4}$ & 7,4 & $<3,0$ \\
\hline Linguiça 4 & $2,2 \times 10^{4}$ & $<3,0$ & $<3,0$ \\
\hline Linguiça 5 & $3,2 \times 10^{4}$ & 3,6 & $<3,0$ \\
\hline Linguiça 6 & $4,2 \times 10^{4}$ & $<3,0$ & $<3,0$ \\
\hline Linguiça 7 & $2,9 \times 10^{5}$ & 110 & $<3,0$ \\
\hline Linguiça 8 & $3,0 \times 10^{5}$ & 46 & $<3,0$ \\
\hline Frango 1 & $5,8 \times 10^{4}$ & 43 & $<3,0$ \\
\hline Frango 2 & $3,5 \times 10^{5}$ & 4.300 & $<3,0$ \\
\hline Frango 3 & $3,2 \times 10^{5}$ & 9,2 & $<3,0$ \\
\hline Frango 4 & $3,0 \times 10^{6}$ & 2.300 & $<3,0$ \\
\hline Frango 5 & $3,4 \times 10^{6}$ & 4.300 & $<3,0$ \\
\hline Carne moída bov. 1 & $1,2 \times 10^{5}$ & 9,2 & 3,6 \\
\hline Carne moída bov. 2 & $3,8 \times 10^{5}$ & 150 & $<3,0$ \\
\hline Carne moída bov. 3 & $8,5 \times 10^{6}$ & $>1.100$ & $<3,0$ \\
\hline Carne moída bov. 4 & $4,4 \times 10^{6}$ & 1400 & $<3,0$ \\
\hline Carne moída bov. 5 & $4,5 \times 10^{7}$ & 15.000 & $<3,0$ \\
\hline Queijo 1 & - & $>11.000 .000$ & $<3,0$ \\
\hline Queijo 2 & - & $>11.000 .000$ & $<3,0$ \\
\hline Queijo 3 & - & $>11.000 .000$ & $<3,0$ \\
\hline Queijo 4 & - & 21.000 & $<3,0$ \\
\hline
\end{tabular}

Fonte: Autores.

O método de contagem de microrganismos em placas é um método geral, capaz de identificar aeróbios mesófilos, quando a temperatura e o tempo de incubação estão corretos (Brasil, 2003). Jay (1998) explica que o procedimento se baseia na premissa de que cada célula microbiana presente em uma amostra irá formar uma colônia separada e visível, quando fixada com meio que lhe permita crescer. Franco e Landgraf (1996) mostram que a técnica de contagem em placas é a mais utilizada nos laboratórios de análise de alimentos. Porém, a contagem de microrganismos mesófilos não é realizada em queijos, pois, em sua fabricação, são utilizadas culturas láticas e, portanto, os queijos são alimentos naturalmente contaminados.

Os critérios para estabelecimento de padrão microbiológico podem ser considerados pela caracterização dos microrganismos e ou suas toxinas, pela classificação dos alimentos segundo o risco epidemiológico, pelos métodos de análise que permitam a determinação dos microrganismos e outros critérios, quando evidências científicas o justifiquem. Esses padrões microbiológicos nos mostram os limites toleráveis de microrganismos para um determinado alimento, condenando produtos que ultrapassem esse limite, garantindo a saúde da comunidade (Brasil, 2011).

Em relação aos coliformes termotolerantes (que indicam uma grande chance de contaminação por fezes), observa-se que nenhuma amostra apresentou alta população que desfavoreça o produto.

O Código Sanitário do Estado de São Paulo (São Paulo, 1992) determina, para alguns alimentos analisados no presente trabalho, que as características microbiológicas sejam as seguintes:

Carnes (bovina, suína, frango) cruas, preparadas ou não, miúdos: 
- Contagem padrão em placas: $\leq 3,0 \times 106 \mathrm{UFC} / \mathrm{g}$

- Bactérias do grupo coliforme de origem fecal (NMP): $\leq 3,0 \times 102 / \mathrm{g}$

Carnes frescas preparadas embutidas:

- Contagem padrão em placas: $\leq 106 \mathrm{UFC} / \mathrm{g}$

Para coliformes totais e termotolerantes, a ANVISA, pela Resolução RDC n 12, de 2 de janeiro de 2001, determina que o número máximo deve ser de 103 para todos os produtos deste trabalho.

A Tabela 1 demonstra as populações de mesófilos, coliformes totais e termotolerantes encontradas nas amostras de alimentos. Verifica-se que:

- População mesofílica:

$>$ Salsicha: variou de 102 a $104 \mathrm{UFC/g}$

$>$ Linguiça: variou de 103 a $105 \mathrm{UFC} / \mathrm{g}$

$>$ Carne moída bovina: variou de 105 a 107 UFC/g

> Frango: variou de 105 a 106 UFC/g.

Percebe-se que três amostras de carne moída (60\%) e duas de frango (40\%) apresentaram população mesofílica superior a 106 UFC/g, evidenciando péssimas condições higiênico-sanitárias de alimentos cárneos, trazendo risco à saúde do consumidor. Já nas amostras de salsicha e linguiça, a população pode ser considerada baixa principalmente por se tratarem de produtos cozidos (salsicha), o que elimina muitos microrganismos mais sensíveis ao calor, e pela presença de nitrito e conservantes (linguiça), o que diminui a taxa de multiplicação microbiana.

- Coliformes totais:

$>$ Salsicha: variou de $<3,0$ a $21 \mathrm{NMP} / \mathrm{g}$

$>$ Linguiça: variou de <3,0 a $110 \mathrm{NMP} / \mathrm{g}$

$>$ Carne moída bovina variou de 9,2 a $15.000 \mathrm{NMP} / \mathrm{g}$

$>$ Frango: variou de 9,2 a 4.300 NMP/g

$>$ Queijo: variou de 21000 a >11.000.000 NMP/g

Percebe-se que nas amostras de salsicha não foram encontradas grandes populações de coliformes totais. Das 30 amostras analisadas, oito (27\%) não atendiam à legislação (Anvisa, 2001). Já nas amostras de linguiça, as de número 7 e 8 indicaram uma população mais elevada quando comparadas com as da salsicha. Observa-se que, em três amostras de peito de frango (60\%), três de carne moída (60\%) e em todas de queijo, a população de coliformes totais chegou a ser superior a 1000 $\mathrm{NMP} / \mathrm{g}$, o que é considerado muito elevado, sendo potencialmente perigoso e inviável para o consumo.

As figuras a seguir indicam a frequência de alimentos considerados contaminados, classificados como "reprovados" ou "aprovados", usando o limite microbiológico de $106 \mathrm{UFC/g}$ para mesófilos e $1000 \mathrm{NMP} / \mathrm{g}$ para coliformes totais e termotolerantes, baseando-se na Resolução RDC nº 12, de 02 de janeiro de 2001 e o código sanitário do Estado de São Paulo de 1992. 
Figura 1 - Relação entre amostras de salsicha aprovadas e reprovadas para mesófilos.

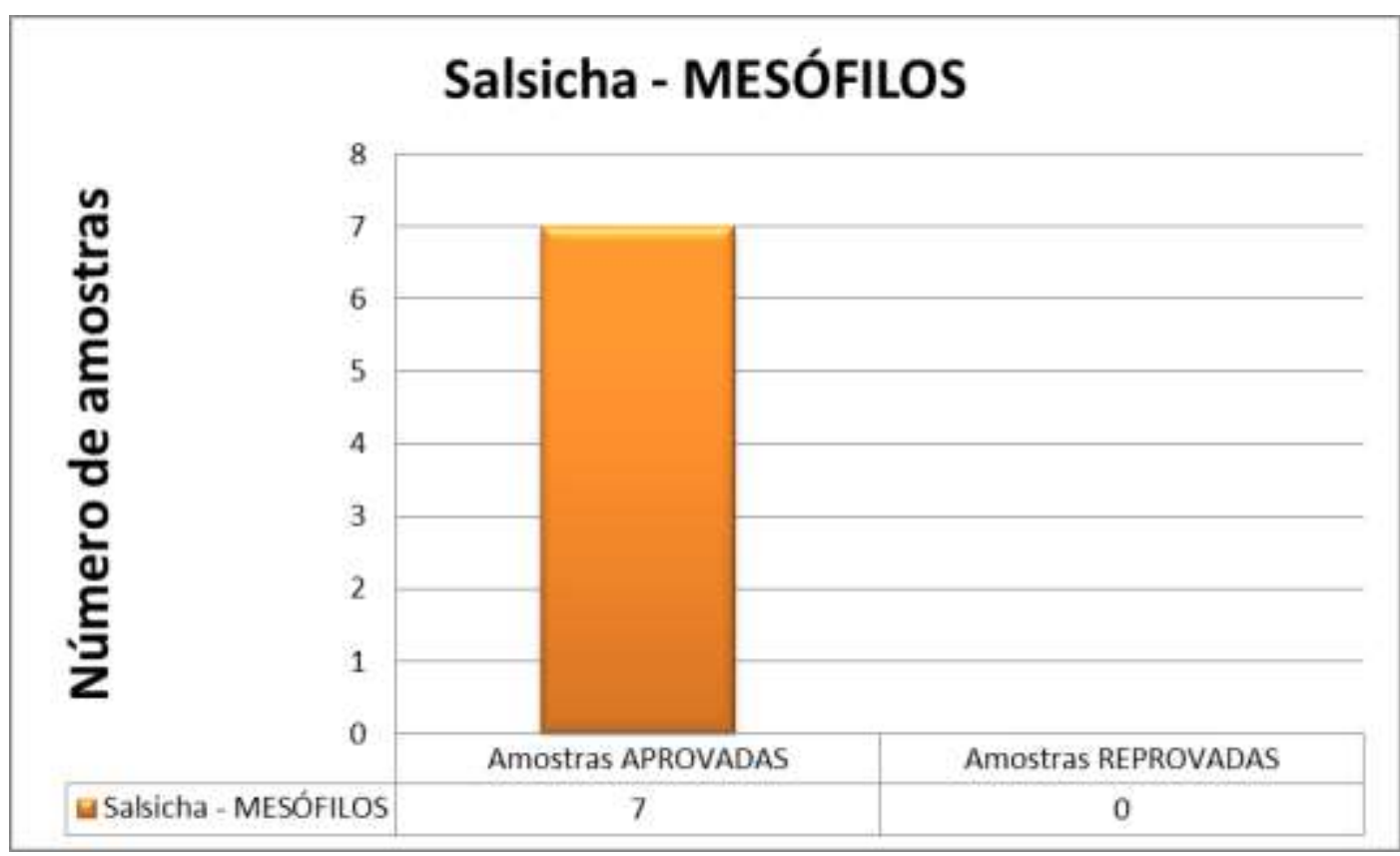

Fonte: Autores.

Carvalho et al. (2005) encontraram em amostras de salsicha, resultados para mesófilos entre $<1,0 \times 10^{1}$ à $2,0 \times 10^{2}$

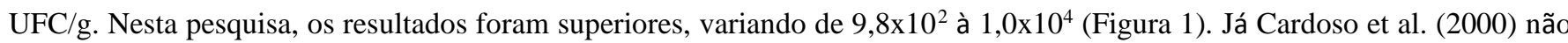
detectaram a presença de mesófilos em salsichas produzidas em abatedouros na cidade de Descalvado/SP.

Figura 2 - Relação entre amostras de salsicha aprovadas e reprovadas para coliformes totais e termotolerantes.

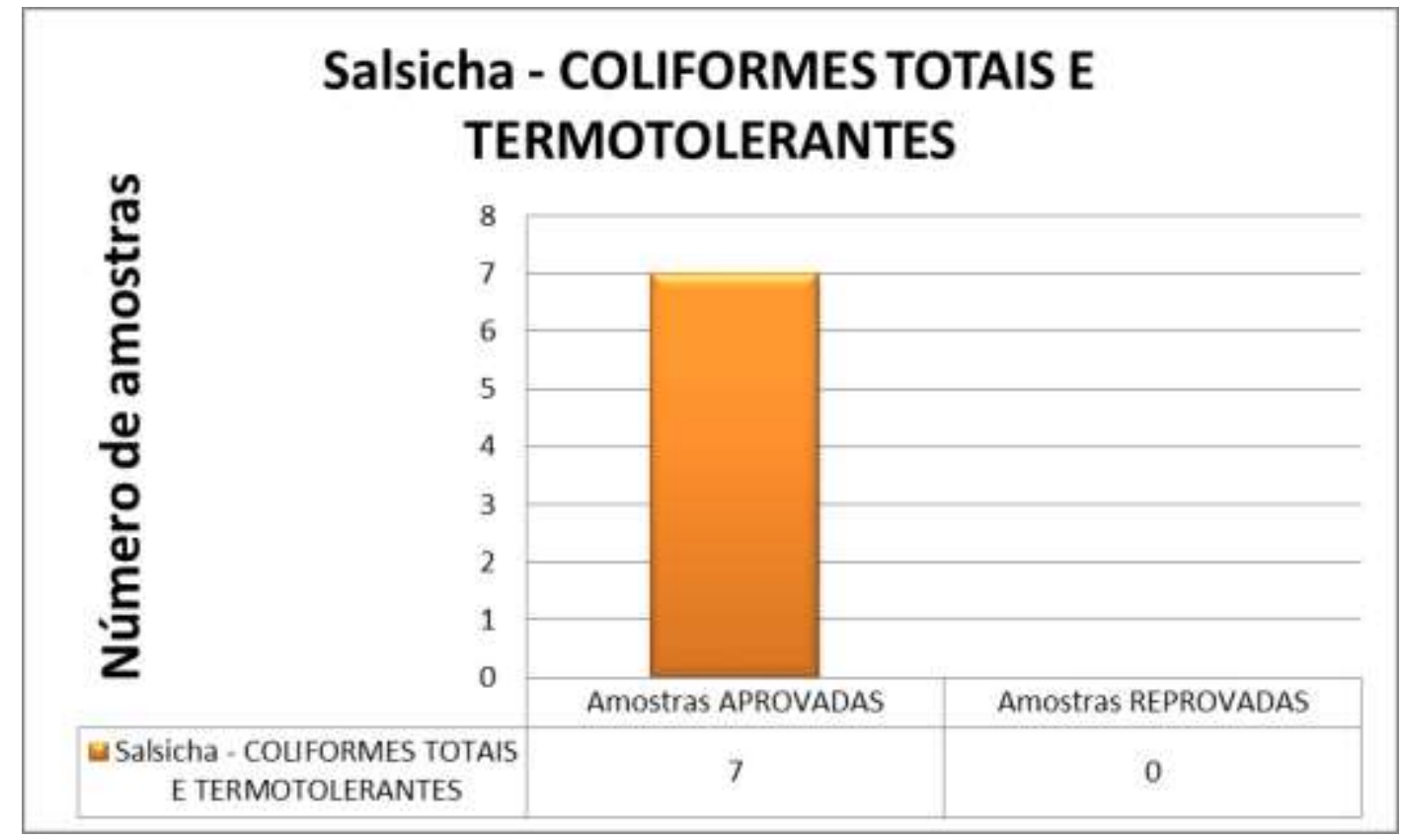

Fonte: Autores. 
Assim como nesta pesquisa (Figura 2), Carvalho et al. (2005) também não detectaram grandes populações de coliformes totais e termotolerantes. Cardoso et al. (2000) também não detectaram presença de termotolerantes, porém, $25 \%$ de suas amostras se mostraram positivas para coliformes totais.

Figura 3 - Relação entre amostras de linguiça aprovadas e reprovadas para mesófilos.

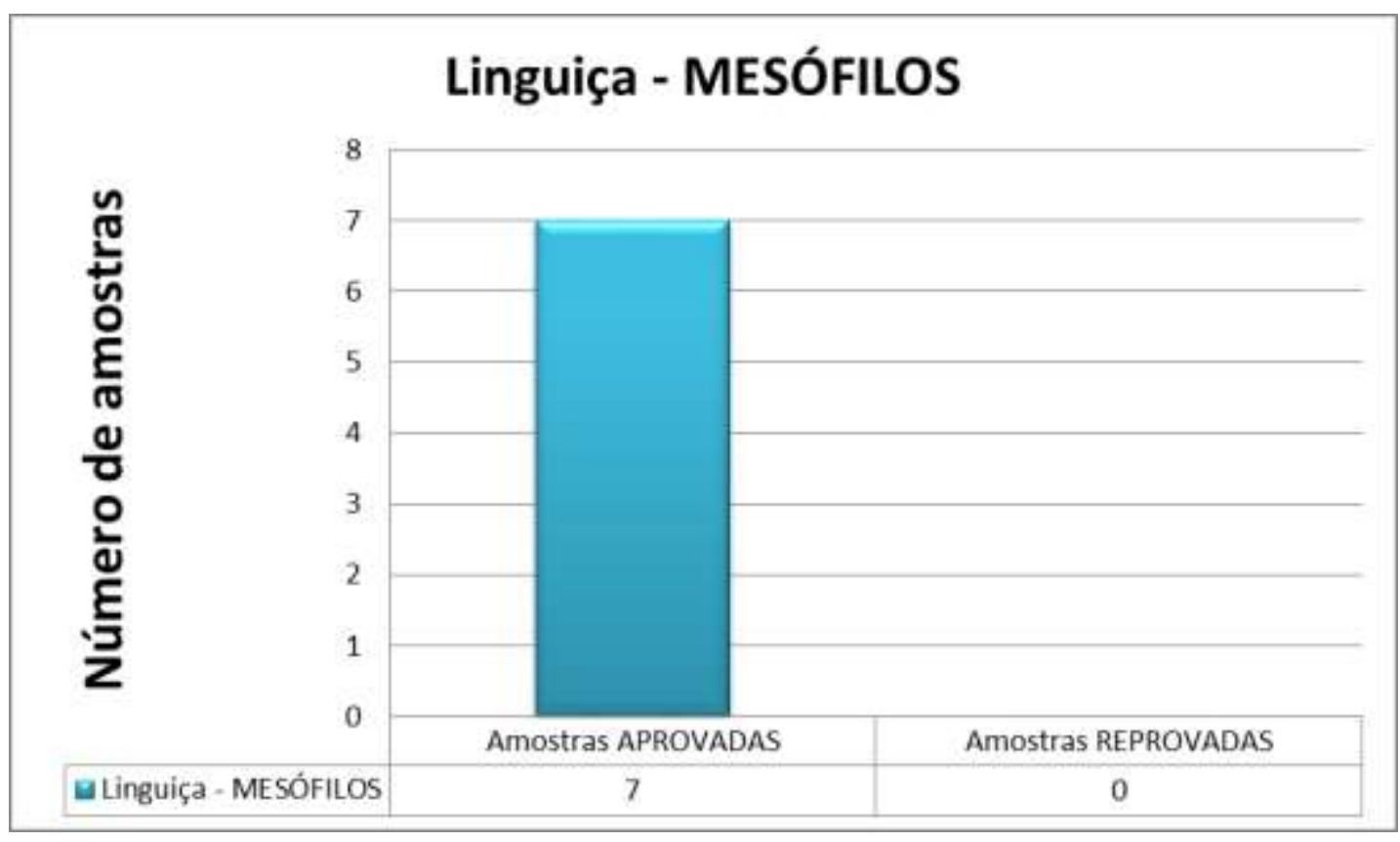

Fonte: Autores.

Na Figura 3, os valores obtidos são inferiores aos encontrados nas análises realizadas por Sabioni et al. (1999), em que a maioria das amostras excederam a $10^{6} \mathrm{UFC} / \mathrm{g}$, e foram inferiores também aos obtidos por Falcão et al., citados por Sabioni et al. (1999), em que $90 \%$ das amostras excederam a $10^{6} \mathrm{UFC} / \mathrm{g}$. Silva (2002) encontrou na linguiça o mínimo de 2,9x $10^{5}$, número máximo encontrado no presente trabalho. Carvalho et al. (2005) detectaram valores equivalentes aos deste trabalho, com resultados entre $8,0 \times 10^{2}$ à $6,5 \times 10^{4}$. Cardoso et al. (2000) não detectaram mesófilos em sua pesquisa. 
Figura 4 - Relação entre amostras de linguiça aprovadas e reprovadas para coliformes totais e termotolerantes.

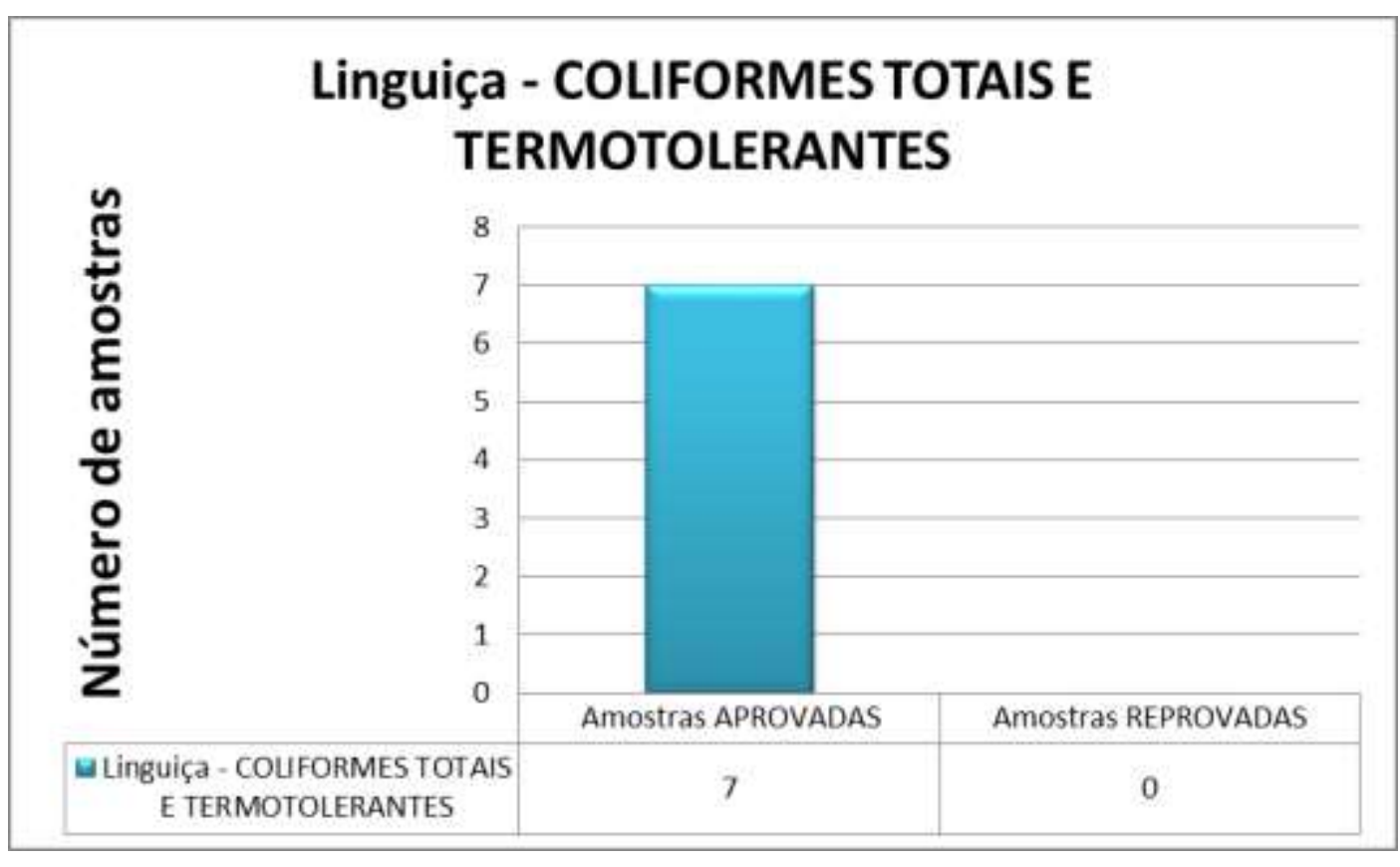

Fonte: Autores.

Sabioni et al. (1999) encontraram mais de $80 \%$ das amostras de linguiça frescal apresentando contagens de coliformes totais inferiores a $10^{5} \mathrm{NMP} / \mathrm{g}$, no presente trabalho, todas as amostras apresentaram valores abaixo de $10^{5} \mathrm{NMP} / \mathrm{g}$

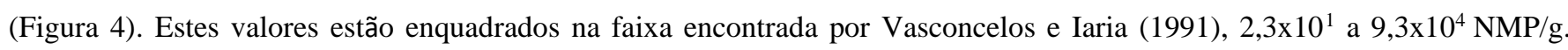
Silva (2002) encontrou valores abaixo de $10^{2} \mathrm{NMP} / \mathrm{g}$, valores iguais aos encontrados na presente pesquisa. Carvalho et al. (2005) detectaram valores superiores para coliformes totais (CT) e termotolerantes (CTT), quando comparados aos desta

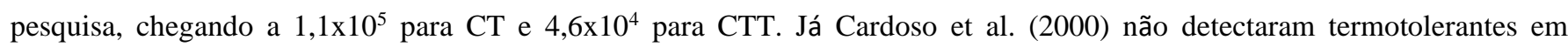
linguiças, mas $12,5 \%$ das amostras foram positivas para $\mathrm{CT}$. 
Figura 5 - Relação entre amostras de frango aprovadas e reprovadas para mesófilos.

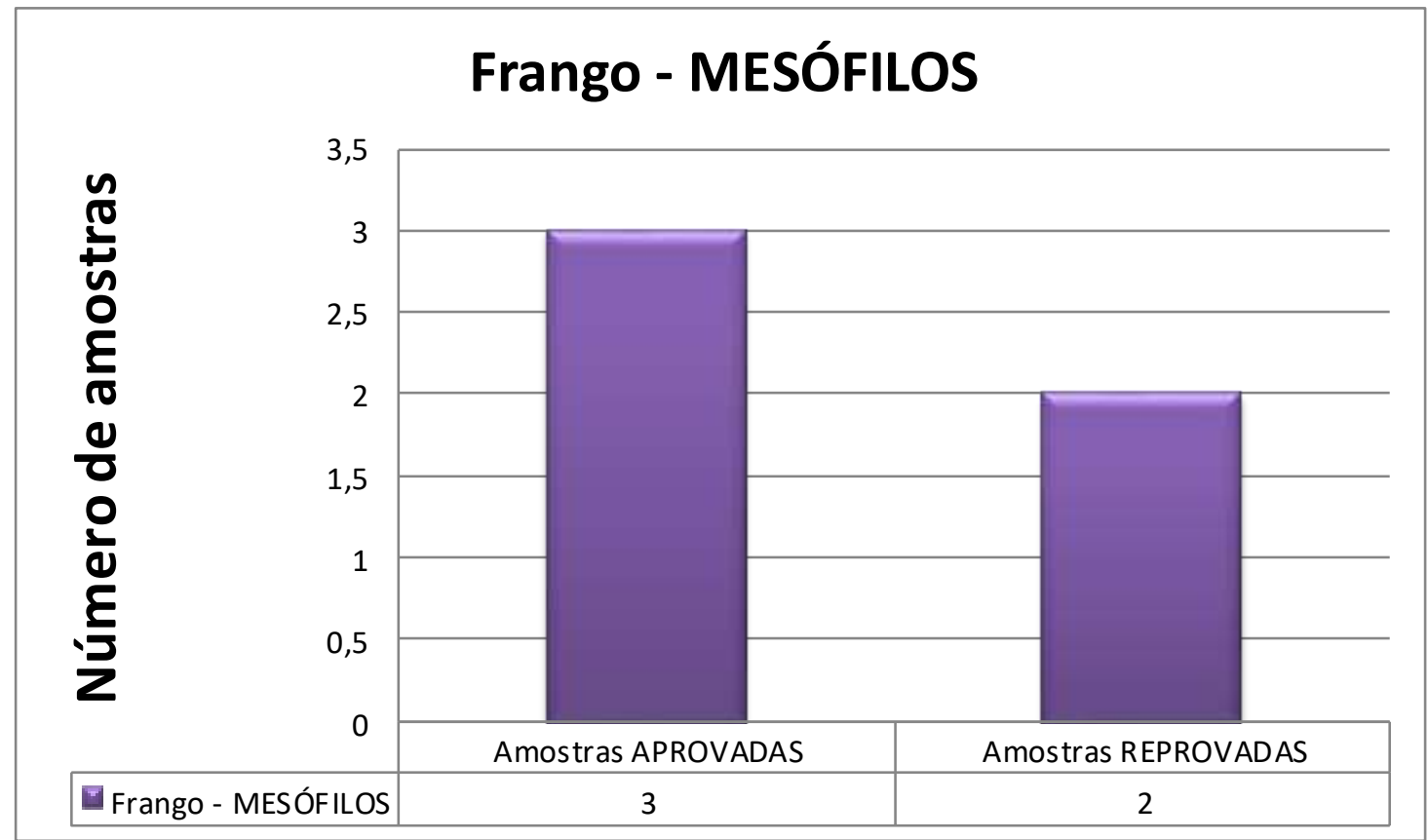

Fonte: Autores.

Os resultados de mesófilos obtidos em frangos por Hoffmann et al. (1995) variaram de 5,8x103 a 2,3x104 UFC/g. Silva (2002) encontrou resultados entre 2,0x106 e 3,0x106. Portanto, pode-se concluir que no presente trabalho, os resultados encontrados foram maiores que os do primeiro autor e três amostras foram menores que os do segundo autor citado (Figura 5). Os resultados obtidos por Hoffmann et al. (1995), estão dentro do limite aceitável de 106, isto já não acontece com os de Silva (2002). Cardoso et al. (2000) não detectaram mesófilos em frangos de abatedouro.

Figura 6 - Relação entre amostras de frango aprovadas e reprovadas para coliformes totais.

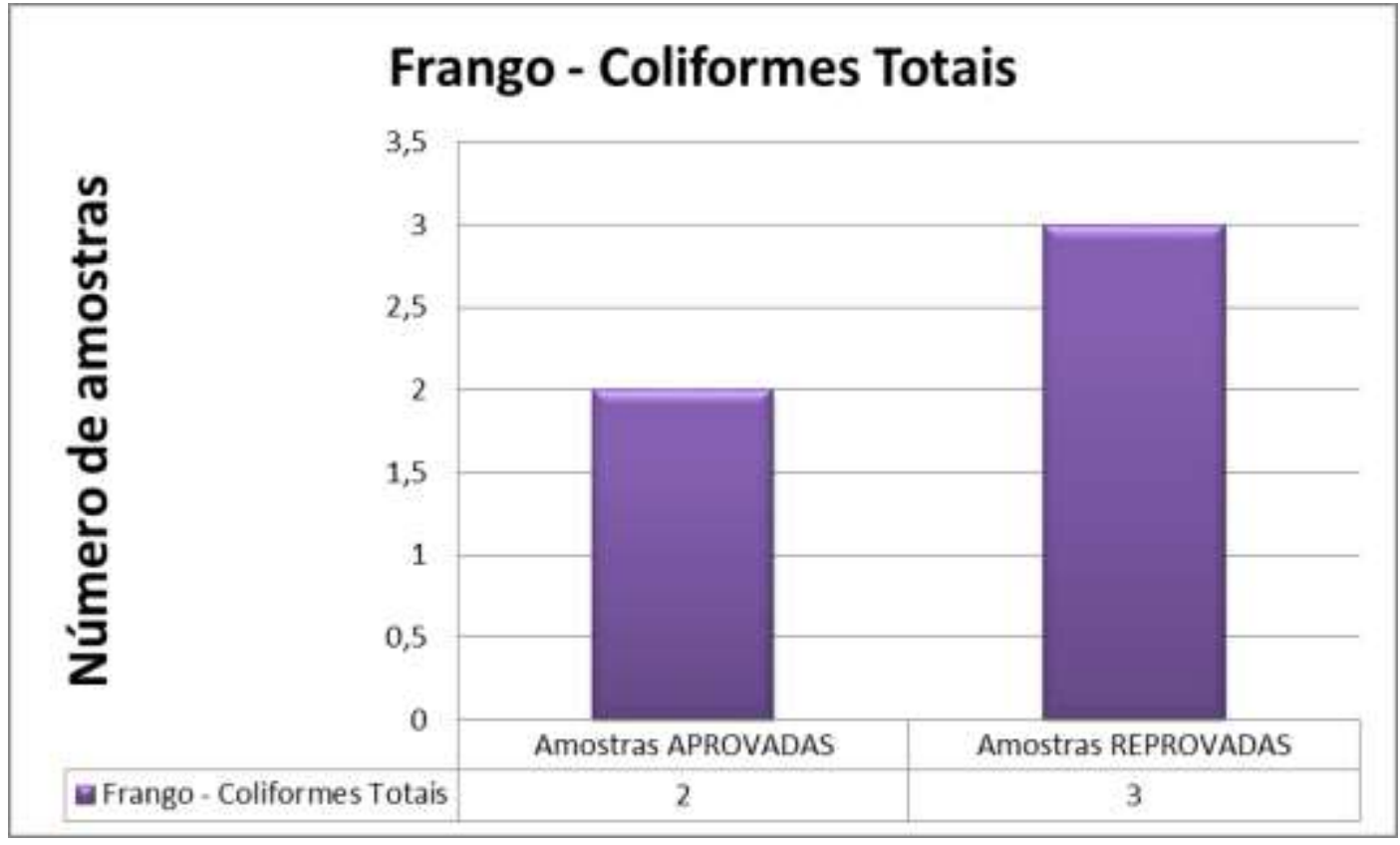

Fonte: Autores. 
Os valores obtidos em duas amostras no presente trabalho foram próximos aos obtidos por Hoffmann et al. (1995)

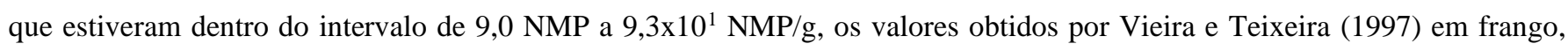

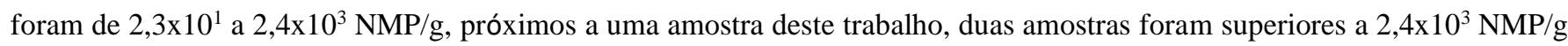
(Figura 6).

Figura 7 - Relação entre amostras de frango aprovadas e reprovadas para coliformes termotolerantes.

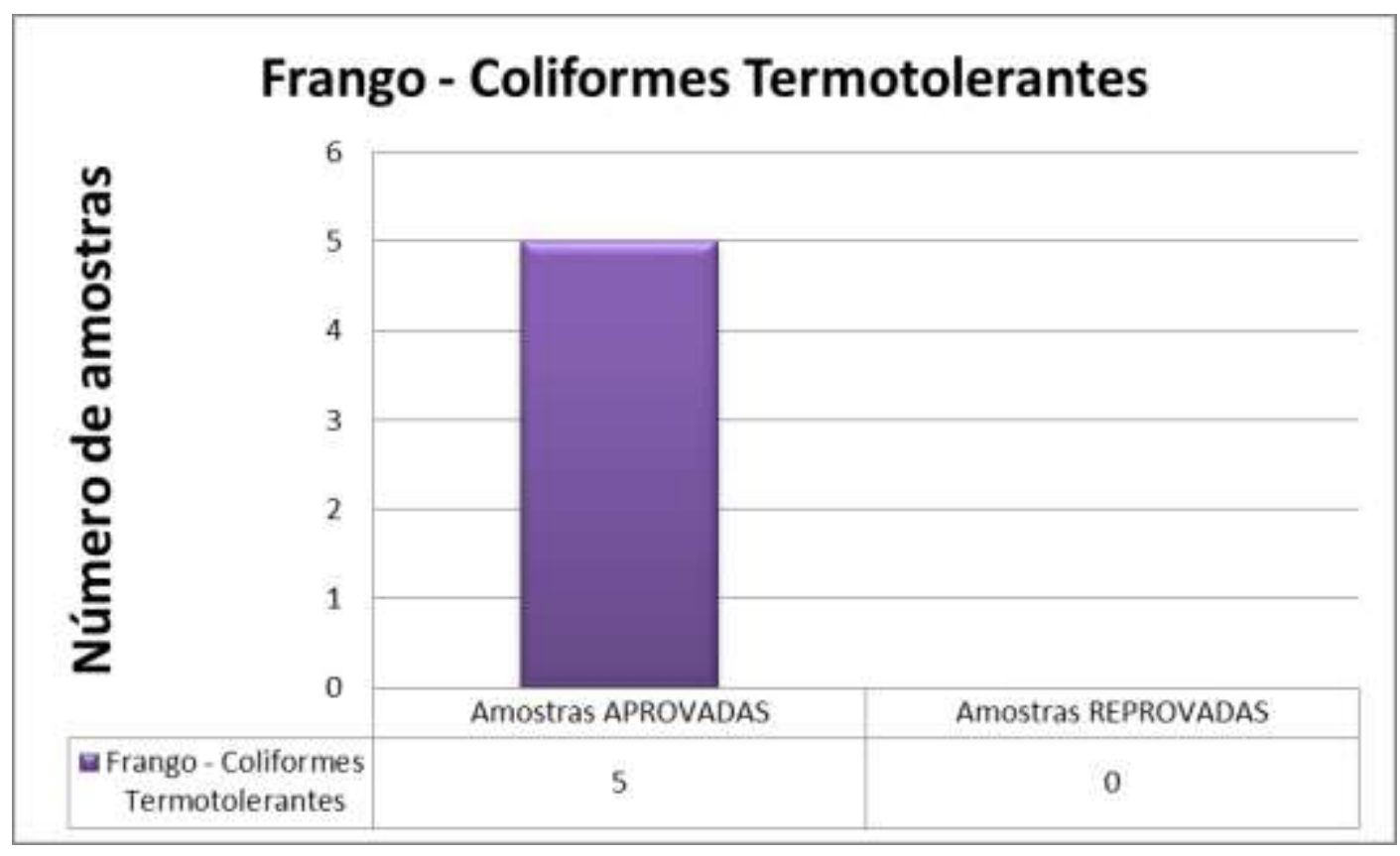

Fonte: Autores.

Cardoso et al. (2000), pesquisando em abatedouros, não observaram presença de coliformes termotolerantes em carne de frango, assim como nesta pesquisa, indicando boas práticas de manipulação e extinguindo qualquer hipótese de contaminação por fezes (Figura 7) 
Figura 8 - Relação entre amostras de carne moída bovina aprovadas e reprovadas para mesófilos.

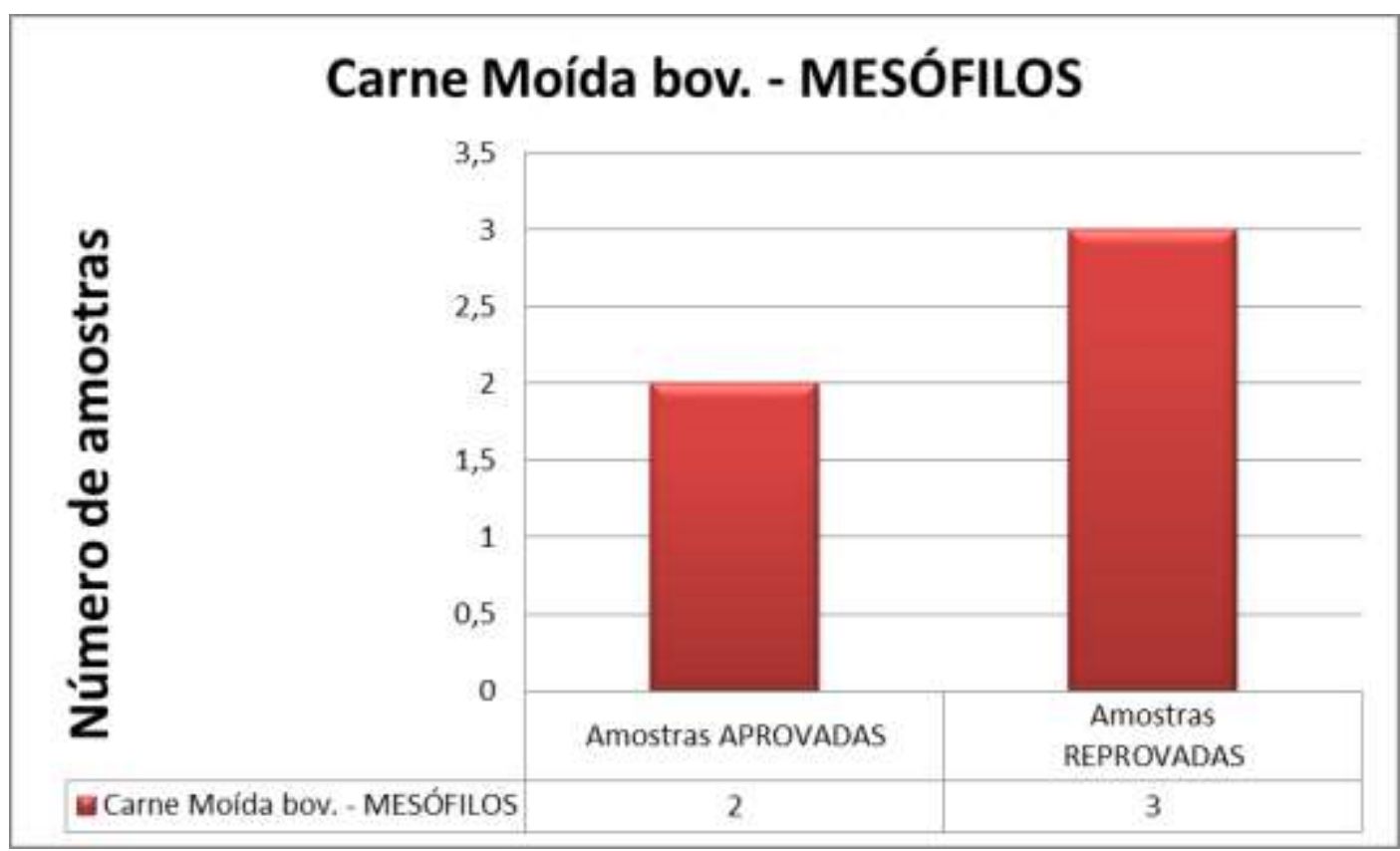

Fonte: Autores.

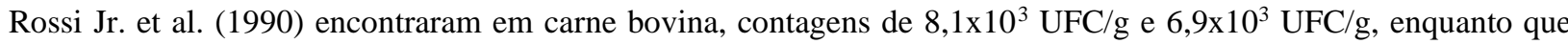
Hoffmann et al. (1998) encontraram para carne bovina moída contagens de $1,0 \times 10^{3}$ a 4,6x10 ${ }^{3}$ UFC/g. Esses valores são inferiores aos do presente trabalho (Figura 8). Silva (2002) encontrou resultados próximos aos desta pesquisa, utilizando a mesma metodologia. Cipriano (2021) comparou contagem de microrganismos aeróbios mesófilos entre hipermercados e mercados de bairros, para hipermercados o valor mínimo foi 2,9 x $10^{5} \mathrm{UFC} / 25 \mathrm{~g}$ e o máximo $1,3 \times 10^{7} \mathrm{UFC} / 25 \mathrm{~g}$. Enquanto nos mercados de bairros o valor mínimo foi $2,8 \times 10^{5} \mathrm{UFC} / 25 \mathrm{~g}$ e o máximo 4,4 x $10^{7} \mathrm{UFC} / 25 \mathrm{~g}$.

Figura 9 - Relação entre amostras de carne moída bovina aprovadas e reprovadas para coliformes totais.

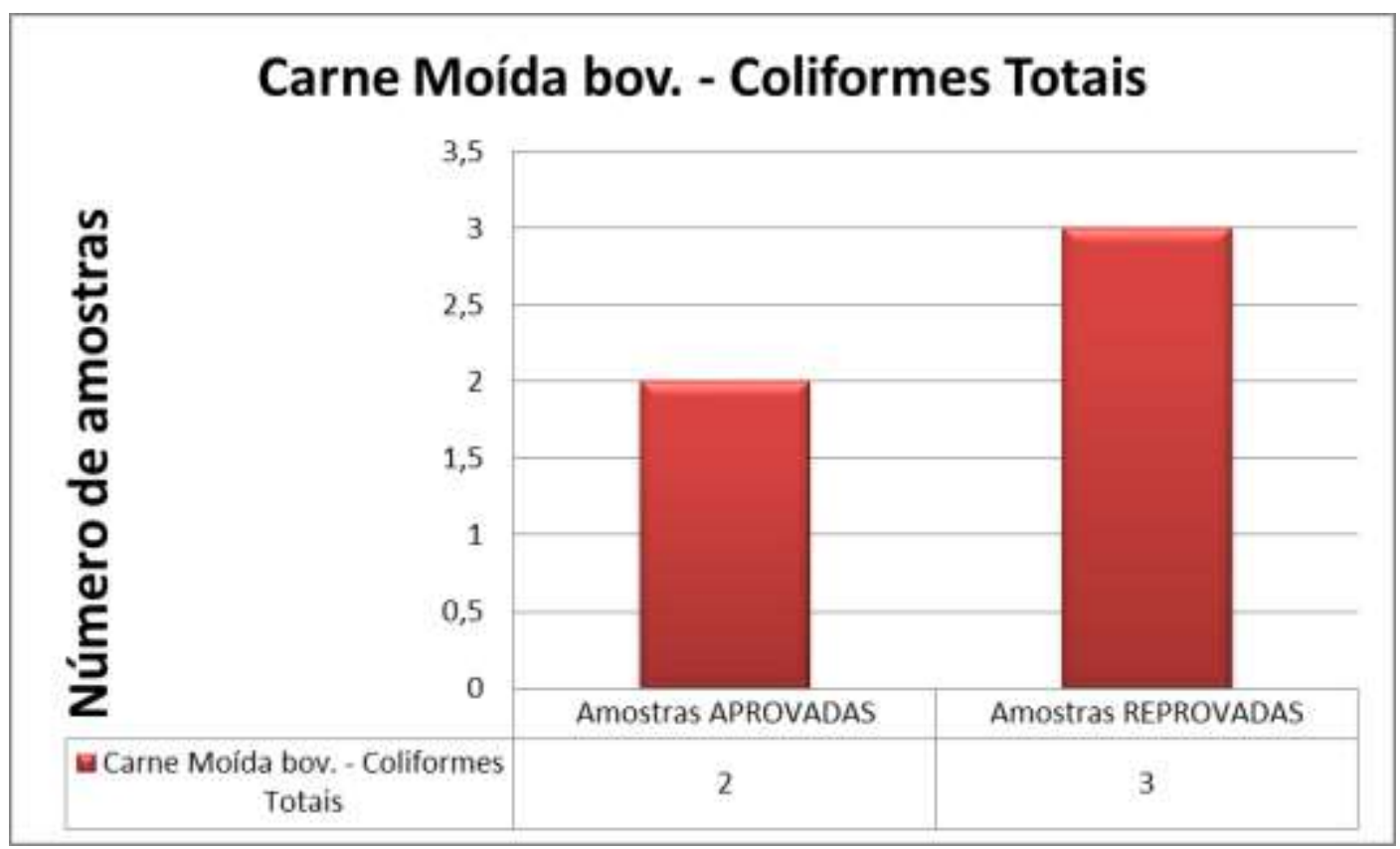

Fonte: Autores. 
Hoffmann et al. (1998), para carne bovina moída, encontraram de 4,0 NMP a 75 NMP/g nas amostras analisadas, valores próximos com duas das amostras deste trabalho. Para Silva (2002), a carne tem sua carga microbiana aumentada à medida que passa por novos cortes ou picagem e, portanto, os valores encontrados no presente trabalho para amostras de carne bovina em um só corte são considerados altos quando comparados aos valores encontrados pelos pesquisadores citados (Figura 9).

Rossi et al. (1990) encontraram contagens inferiores para coliformes totais, 59 NMP/g (desossa em mesa) e 35 NMP/g (desossa aérea). Quase metade das amostras de carne bovina analisadas por Tanaka et al. (1997) tiveram os valores compreendidos entre 10 e 1000 NMP/g, enquanto que aproximadamente 40\% foram acima de 1000 NMP/g, valores parecidos com os da presente pesquisa.

Hangui et al. (2015) observaram que, para coliformes termotolerantes, 100\% das amostras apresentaram valores abaixo do limite previsto em lei que é de $10^{3} \mathrm{NMP} / \mathrm{g}$. O maior valor encontrado foi de 2,6 x $10^{2} \mathrm{NMP} / \mathrm{g}$. Isto não acontece com o presente trabalho, pois, todas as amostras apresentaram valores menores que 3,6 NMP/g (Figura 10).

Nascimento et al. (1985) encontraram também desde ausência, como Silva (2002) também encontrou, até o valor máximo de $1,1 \times 10^{8} \mathrm{NMP} / \mathrm{g}$. Portanto, as amostras do presente trabalho estão de acordo com o autor citado anteriormente (Figura 11). Já Santana et al. (2008), encontram valor médio de 1,07x10³, valor muito abaixo dos desta pesquisa. A qualidade higiênico-sanitária dos queijos Minas frescal, produzidos artesanalmente e comercializados em feiras-livres, é muito precária, constituindo riscos à saúde do consumidor devido a qualidade inadequada das matérias-primas e/ou condições impróprias de processamento, estocagem e comercialização (Ferreira et al., 2011).

Figura 10 - Relação entre amostras de carne moída bovina aprovadas e reprovadas para coliformes termotolerantes.

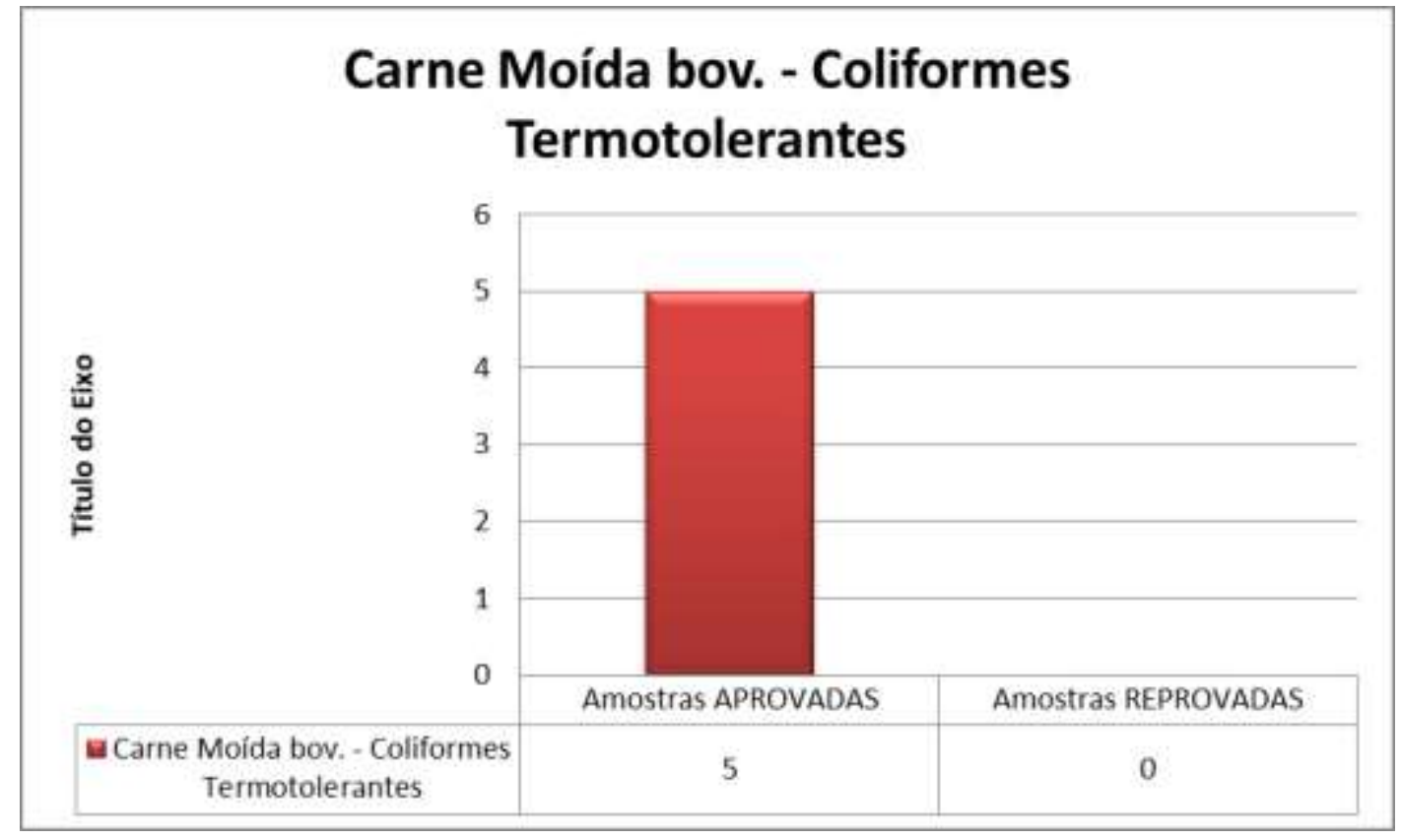

Fonte: Autores. 
Figura 11 - Relação entre amostras de queijo sem SIF aprovadas e reprovadas para coliformes totais.

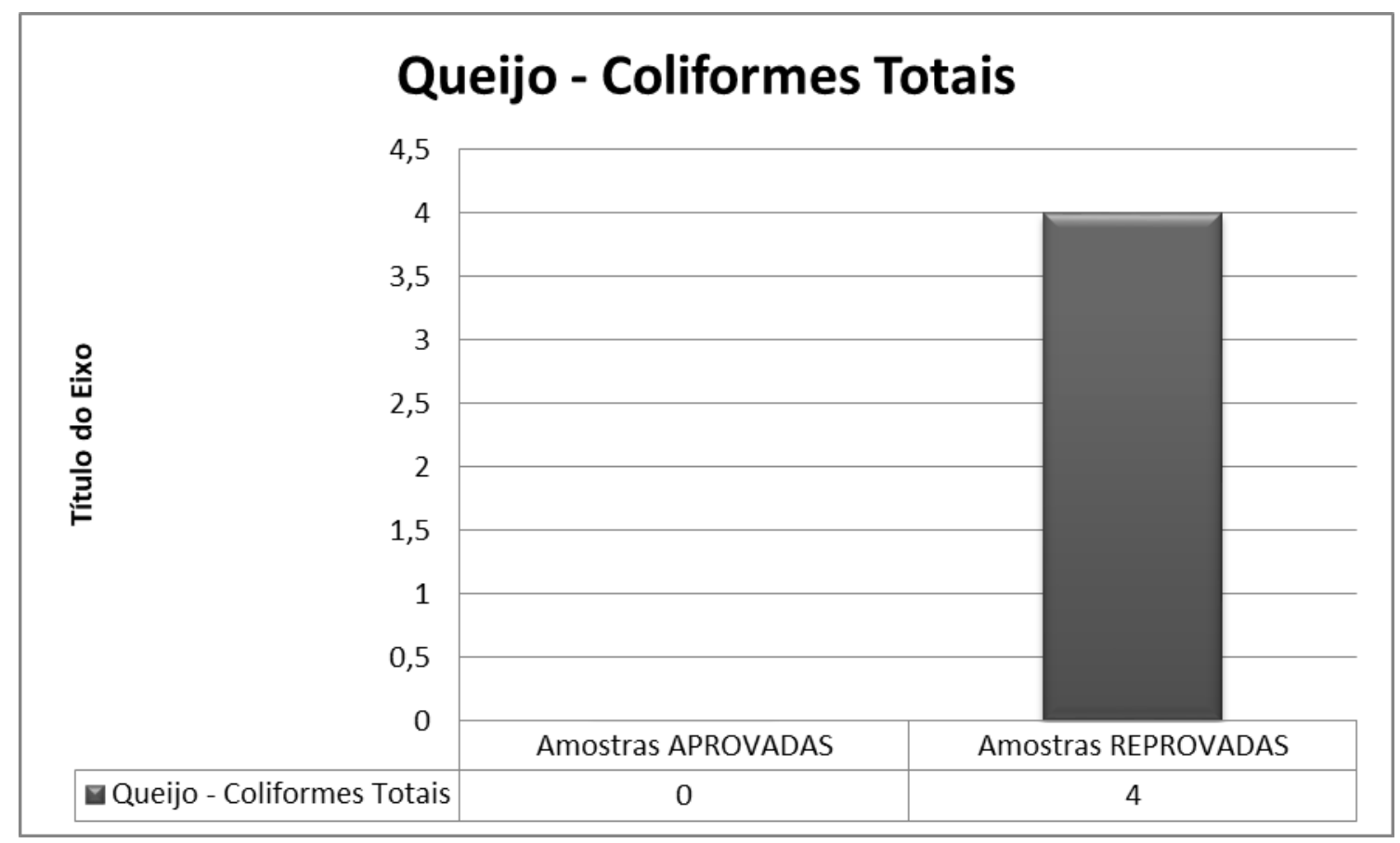

Fonte: Autores.

Figura 12 - Relação entre amostras de queijo sem SIF aprovadas e reprovadas para coliformes termotolerantes.

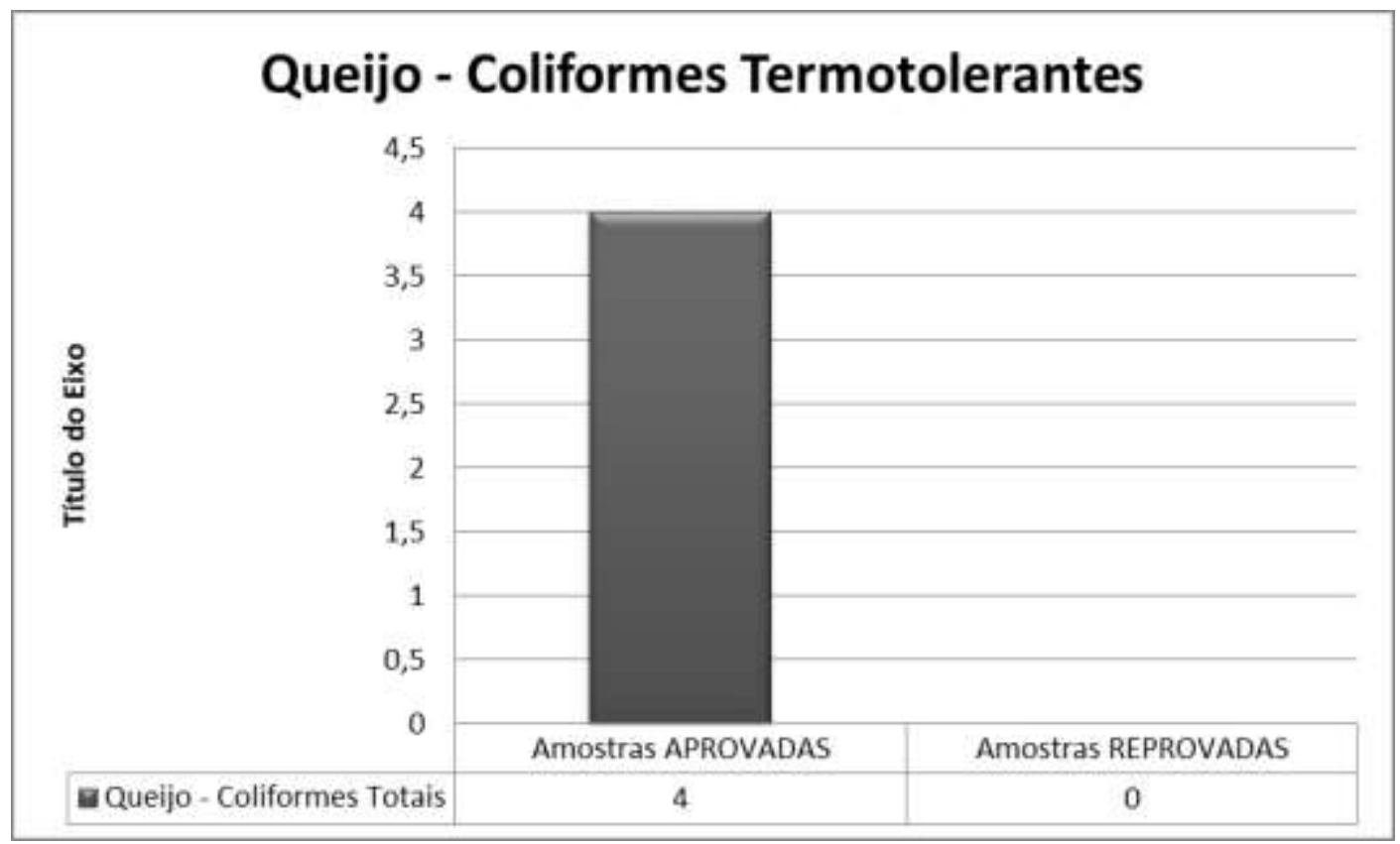

Fonte: Autores.

Ferreira et al. (2011) encontraram em sua pesquisa valores de $<2,0 \times 10^{2} \mathrm{a} \geq 1,1 \times 10^{4} \mathrm{NMP} / \mathrm{g}$ para coliformes termotolerantes, Santana et al. (2008) encontraram valor médio de $8,58 \times 10^{2}$, valores diferentes dos da presente pesquisa, onde não foi detectada nenhuma amostra positiva para esse microrganismo (Figura 12).

Com base em todos os resultados expostos, sugere-se que treinamentos sobre contaminação e higienização sejam feitos periodicamente para aprendizado de manipuladores que atuarão no setor de alimentos, assim como as regras desse 
treinamento devem ser adotadas pelos colaboradores e realizadas de forma rigorosa. O comprometimento da equipe no setor de alimentos é essencial para que o objetivo seja alcançado e as boas práticas de manipulação tenham sucesso. Através dessas maneiras educativas, os alimentos obtidos pelos consumidores em supermercados terão sua carga microbiológica reduzida, tornando o alimento de qualidade e saudável, livre de patógenos.

Infelizmente, a legislação que limita a quantidade de mesófilos em alimentos é estadual, ficando a critério de cada estado definir a carga microbiana tolerável, isso pode gerar dúvidas em relação ao limite a ser usado por cada empresa e também pode servir como um mecanismo para burlar a lei, aproveitando dessa variação de carga microbiana que cada estado define. Já a Agência Nacional de Vigilância Sanitária, que é um órgão federal, pela Resolução RDC no 12, de 2 de janeiro de 2001, diz que alimentos cárneos devem ser apenas livres de Salmonella e devem ter limite de $10^{3}$ de coliformes totais e termotolerante. Cabe, então, as autoridades sanitárias uma melhor fiscalização e orientação de manipuladores de alimentos para garantir a saúde pública.

\section{Conclusão}

Com base nos resultados obtidos e nas condições em que o presente trabalho foi realizado, conclui-se que nem todos os alimentos oferecidos aos consumidores apresentam adequada qualidade higiênico-sanitária. Cabe às autoridades a elaboração de leis eficientes e a fiscalização constante dos alimentos expostos à venda para garantir a segurança dos alimentos. Ainda, conclui-se que alimentos mais processados apresentam menor contaminação microbiana do que aqueles não processados.

É necessário que haja mais linhagens de pesquisas na área de inspeção alimentar, que avalie todo o processo produtivo, desde a obtenção da matéria prima até a chegada ao consumidor final, tanto dos produtos, quanto dos subprodutos de origem animal que são comercializados, para avaliar o procedimento realizado e a qualidade higiênico-sanitária do produto final, com o intuito de garantir segurança alimentar a quem for consumir.

\section{Referências}

Brasil (2003). Instrução Normativa $n^{\circ} 62$ de 26 de agosto de 2003, Métodos analíticos oficiais para análises microbiológicas para controle de produtos de origem animal e água. Diário Oficial [da União], Brasília, seção1, p.14. http://extranet.agricultura.gov.br/sislegis-consulta/servlet/VisualizarAnexo?id=6078

Brasil (2001). Resolução RDC n 12 , de 2 de janeiro de 2001. Aprova o "Regulamento técnico sobre padrões microbiológicos para alimentos". Órgão emissor: ANVISA-Agência Nacional de Vigilância Sanitária. www.anvisa.gov.br =>.

Cardoso, A. L. S. P., Tessari, E. N. C., Castro A. G. M. \& Kanashiro, A. M. I. (2000). Pesquisa de Salmonella SP., coliformes totais, coliformes fecais e mesófilos em carcaças e produtos derivados de frango. Arquivo do Instituto de Biologia, 67(1), 25-30.

Carvalho, A. C. F. B., Cortez, A. L. L., Salotti, B. M., Burger, K. P. \& Vidal-Martins, A. M. C. (2005). Presença de microrganismos mesófilos, psicrotróficos e coliformes em diferentes amostras de produtos avícolas. Arquivo do Instituto de Biologia, 72(3), 303-307.

Cipriano, L. C., de Sousa, L. B., de Godoy Siqueira, H. P., Lima, E. F., Messias, C. T., de Marchi, P. G. F., de Medeiros, E. S., Hoppe, I. B. A. L. \& de Siqueira, AB (2021). Vida útil de carne bovina moída comercializada no Município de Boa Vista - Roraima. Research, Society and Development, 10(2), e19010212282-e19010212282.

Doyle, M. P., Beuchat, L. R. \& Montville, T. J. (1997). Food Microbiology: Fundamentals and Frontiers, Editora.

Ferreira, H., Lima, H \& Coelho, T. (2014). Microrganismos indicadores em alimentos de origem animal. Programa de Pós-graduação em Ciência Animal PPGCA da Universidade Federal Rural do Semiárido - UFERSA. http://www2.ufersa.edu.br/portal/view/uploads/setores/126/Resu mo\%20MO\%20indicadores.\%20Heider,\%20Hiagos, \%20Thiago.pdf

Ferreira, M. S. F. (2006). Contaminação de alimentos ocasionada por manipuladores. Programa de Pós-graduação Lato Sensu, Curso de Especialização em Qualidade em Alimento, Universidade de Brasília.

Ferreira, R. M., Spini, J. D. C. M., Carrazza, L. G., Sant'ana, D. S., de Oliveira, M. T., Alves, L. R. \& Carrazza, T. G. (2011). Quantificação de coliformes totais e termotolerantes em queijo Minas Frescal artesanal. PUBVET, 5 (5), Ed. 152, Art. 1022.

Franco, B. D. G. M \& Landgraf, M. (1996). Microbiologia de alimentos. Atheneu.

Franco, B. D. G. M. (2003). Microbiologia dos Alimentos. Atheneu. 
Franco, R. M. \& Almeida, L. E. F. (1992). Avaliação microbiológica de queijo ralado, tipo parmesão, comercializado em Niterói, RJ. Revista Higiene Alimentar, 6(21), 33-36.

Freitas, L. H. (1995). Sistema especialista para diagnóstico de toxinfecções alimentares de origem bacteriana. Dissertação (Mestrado em Ciência e Tecnologia de Alimentos) - Universidade Federal de Viçosa, Viçosa.

Hangui, S. A. R., Pereira, A. F., Dourado, A. T. D. S., Martins, J. D., Vargem, D. D. S. \& da Silva, J. R. (2015). Análise microbiológica da carne moída comercializada na cidade de Anápolis, Goiás, Brasil. Revista Eletrônica de Farmácia, Anápolis REF-ISSN1808-0804, 12(2), $30-38$.

Hattori, N. A \& Klaus, I. C. (2013). Avaliação microbiológica e higiênico-sanitária em uma panificadora no município de Missal-PR. Paraná. Trabalho de conclusão de curso da Universidade Tecnológica Federal do Paraná, curso de Tecnologia em Alimentos, campus Medianeira.

Hayes, P. R. (1995). Food microbiology and hygiene. (2a ed.), Chapman and Hall.

Hoffmann, F. L., Garcia-Cruz, C. H. \& Vinturim, T. M. (1995). Estudo higiênico sanitário de frangos comercializados na cidade de São José do Rio Preto-SP. Higiene Alimentar, 9(35), 31-33.

Hoffmann, F. L., Garcia-Cruz, C. H \& Vinturium, T. M. (1998). Qualidade microbiológica de amostras de carnes e de presunto. Higiene Alimentar, 12(58), $52-57$.

ICMSF (International Commission On Microbiological Specifications For Foods) (1994). Microrganismos de los alimentos. 1. Técnicas de análisis microbiológico. Acribia.

Jay, J. M. (1998). Modern food microbiology. (5a ed.), Aspen Publishers.

Nascimento, D., Sabioni, J. G., Pimenta, N. \& Xandó, S. R (1985). Avaliação microbiológica de queijos tipo Minas-frescal da cidade de Ouro Preto-MG. Boletim da Sociedade Brasileira de Ciência e Tecnologia de Alimentos, 19(2), 120-129.

Oliveira, D. T., Moreira, A., Urnau, L., Noskoski, L. \& Cereser, N. D. (2012). Psicrotróficos na indústria de laticínios. XV Amostra de Iniciação Científica. UNICRUZ, RS.

Pinheiro, M. B., Wada, T. C. \& Pereira, C. A. M. (2010). Análise microbiológica de tábuas de manipulação de alimentos de uma instituição de ensino superior em São Carlos-SP. São Carlos, SP. Centro Universitário Central Paulista (UNICEP).

Ribeiro, F. B. (2008). Avaliação da contribuição para a área de Vigilância Sanitária de Alimentos de pesquisas realizadas em Programas de Pós-Graduação Strictu Sensu da Universidade de São Paulo. São Paulo. Dissertação (Mestrado) - Faculdade de Saúde Pública da Universidade de São Paulo.

Rossi, J. R. O. D., Iaria, S. T., Santos, I. F. \& Berchieri, J. R. A (1990). Carne mecanicamente separada de origem bovina: I - Influência de dois sistemas de desossa manual sobre as características microbiológicas do produto recém obtido. Revista de Microbiologia, 21(4), 324-330.

Sabioni, J. G., Maia, A. R. P. \& Leal, J. A. (1999). Avaliação microbiológica de linguiça frescal comercializada na cidade de Ouro Preto - MG. Higiene Alimentar, 13(61), 110-113.

Santana, R. F., Santos, D. M., Martinez, A. C. C. \& Lima Á. S (2008). Qualidade microbiológica de queijo-coalho comercializado em Aracaju, SE. Arquivos Brasileiros de Medicina Veterinária e Zootecnia, 60(6), 1517-1522.

São Paulo (Estado) (1992). Secretaria da Saúde. Código sanitário: Decreto no 12.342 de 27 de setembro de 1978: regulamento da promoção e recuperação da saúde no campo da competência da Secretaria de Estado da Saúde (revisto e atualizado até dezembro de 1990). (5a ed.), IMESP.

Silva, M. C. (2002). Avaliação da qualidade microbiológica de alimentos com a utilização de metodologias convencionais e do sistema SimPlate. Dissertação (Mestrado) - Escola Superior de Agricultura Luiz de Queiroz, Universidade de São Paulo.

Souza, R. R., Germano, P. M. L. \& Germano, M. I. S. (2003). A manipulação inadequada dos alimentos: fator de contaminação. Revista Higiene Alimentar.

Vasconcelos, J. C. \& Iaria, S. T. (1991). Condições microbiológicas (higiênico-sanitárias) das linguiças frescas comercializadas em feiras livres no município de São Paulo - SP. Indicações de contaminação. Boletim do Centro de Pesquisa e Processamento de Alimentos, 9(1), 64-75.

Vieira, C. R. N \& Teixeira, C. G. (1997). Condições higiênico-sanitárias de carcaças resfriadas de frango comercializadas em Poços de Caldas - MG. Higiene Alimentar, 11(48), 36-40. 